\title{
Dysplasia in Ulcerative Colitis
}

National Cancer Institute

\section{Source}

National Cancer Institute. Dysplasia in Ulcerative Colitis. NCI Thesaurus. Code C45433.

A morphologic finding indicating the presence of dysplastic epithelial changes in a large intestinal tissue sample that is affected by ulcerative colitis. 